\title{
PELATIHAN PEMBUATAN MEDIA PEMBELAJARAN BERBASIS ICT (INFORMATION COMMUNICATION TECHNOLOGI) DI TK RUMAH PELANGI COLOMADU KARANGANYAR
}

\author{
Oka Irmade, Paulus Widjanarko \\ Universitas Slamet Riyadi Surakarta
}

\section{Ringkasan}

Pendidik dituntut untuk selalu mengembangkan kompetensi pedagogik dan profesionalnya baik ditingkat PAUD, Sekolah Dasar, Sekolah menengah bahkan Perguruan tinggi. Salah satu bentuk kompetensi pedagogik dan profesional seorang pendidik adalah kemampuanya dibidang penguasaan (ICT) Information Communication Technologi. Berdasarkan hasil pengamatan yang dilakukan ke TK Rumah Pelangi, Dukuh Banukan RT.06/RW.09 DS. Malangjiwan, Colomadu, Karanganyar penguasaan dan pemanfaatan guru terhadap ICT sangat minim terlebih lagi dalam proses pembuatan media karena masih melum terbiasa dan belum terlatih dalam membuat media berbasis ICT. Sehingga perlu diadakan pelatihan melalui program pengabdian kepada masyarakat. Tujuan yang hendak dicapai dari program pengabdian ini adalah memberikan pemahaman dan keterampilan membuat media pembelajaran berbasis ICT yang berupa Powerpoin menarik, Flipbook dan Comiclife yang di aplikasikan dalam proses pembelajaran.

Metode pelaksanaan pengabdian meliputi: (1) metode pendekatan yang dilakukan mulai tahap survei, perijinan, dan pemberian motivasi bagi guru yang akan mengikuti pelatihan (2) metode pelaksanaan program, meliputi tahap pendahuluan, tahap sosialisasi dan audiensi, tahap pelaksanaan, serta tahap evaluasi akhir.

Hasil yang dicapai dalam pengabdian ini telah mencapai target yang diharapkan, 9 guru yang mengikuti pelatihan, telah mampu membuat media pembelajaran berbasis ICT yang terdiri dari Powerpoin menarik, Flipbook, dan Comiclife. Luaran yang dihasilkan berupa media pembelajaran berbasis ICT serta implementasi media pembelajaran yang digunakan pada materi tertentu dan publikasi artikel pengabdian dalam jurnal ilmiah.

Kata Kunci: Pembuatan Media, ICT 


\section{PENDAHULUAN}

Perkembangan didalam dunia pendidikan memang sangat dipengaruhi oleh perkembangan teknologi. Setiap inovasi dalam teknologi yang diciptakan akan memberikan banyak pengaruh positif. Difusi dari sebuah inovasi juga harus dilakukan dengan maksimal supaya dapat dimanfaatkan secara merata ke segala aspek didalam dunia pendidikan. Pendidik menjadi kunci utama dan berpengaruh besar dalam kemajuan pendidikan. Pendidik dituntut untuk selalu mengembangkan kompetensi pedagogik dan profesionalnya baik ditingkat PAUD, Sekolah Dasar, Sekolah menengah bahkan Perguruan tinggi. Salah satu bentuk kompetensi pedagogik dan profesional seorang pendidik adalah kemampuanya dibidang penguasaan (ICT) Information Communication Technologi (Kemendiknas, 2010).

Menurut British Advisory Council (1980) ICT adalah berbagai aspek yang melibatkan teknologi, rekayasa dan teknik pengolahan yang digunakan dalam pengendalian dan pemrosesan informasi serta penggunaannya, hubungan komputer dengan manusia dan hal yang berkaitan dengan sosial, ekonomi dan kebudayaan. ICT adalah suatu teknologi yang digunakan untuk mengolah data, termasuk memproses, mendapatkan, menyusun, menyimpan, memanipulasi data dalam berbagai cara untuk menghasilkan informasi yang berkualitas. ICT berkembang sangat pesat di berbagai bidang begitu juga dalam dunia pendidikan (Edy, 2008). Penggunaan dan pemanfaatan sistem information and communication technology (ICT) dalam dunia pendidikan sudah menjadi suatu kebutuhan yang wajib dan penggunaanya harus dilandasi dengan prinsip efektif dan efisien. Perangkat yang diperlukan untuk membuat dan mengembangkan media pembelajaran berbasis ICT yaitu terdiri dari perangkat keras (hardware) meliputi: komputer, speaker, scanner, CDROM, DVD-ROM, flashdisk, memoricard, kamera digital, video, sedangkan perangkat lunak (software) meliputi: Power Point, Movie Maker, Flipbook, Paint, Coreldraw, Macromedia flash, Comiclife dan sebagainya.

\section{METODE PELAKSANAAN}

Transfer IPTEKS yang dilakukan Tim Pengabdian dilakukan pada tiap tahapan dengan menggunakan prinsip bahwa setiap inovasi yang diterima oleh mitra sebaiknya melalui proses mendengar, mengetahui, mencoba, mengevaluasi, menerima, meyakini, dan melaksanakan. Melalui proses-proses tersebut diharapkan inovasi dapat diadopsi secara berkesinambungan, serta target sasaran mempunyai kemampuan untuk mengembangkan inovasi yang telah disosialisasikan. Supaya setiap proses berlangsung dengan baik, maka 
penyampaian inovasi kepada mitra ditempuh melalui tahapan penjelasan, diskusi, praktek serta dilakukan tahapan pendampingan.

Langkah awal untuk menyesuaikan paradigma para guru dilakukan melalui penjelaskan latar belakang dan tujuan program yang akan diterapkan serta memberikan motivasi kepada guru TK yang ada di TK Rumah Pelangi, Dukuh Banukan RT.06/RW.09 DS. Malangjiwan, Colomadu, Karanganyar agar program ini dirasakan sebagai kebutuhan untuk mereka jalankan. Caranya dengan mengumpulkan guru-guru tersebut dan berdiskusi bersama. Diharapkan dengan adanya motivasi dan diskusi guru tidak hanya sebagai objek yang hanya pasif menerima pelatihan tetapi ikut berpartisipasi aktif untuk menjalankan program ini dan mengembangkannya agar tujuan dari program ini tercapai.

Metode yang dilakukan adalah sebagai berikut: pertama pendekatan secara partisipatif dan dialogis, yaitu dengan cara menghubungi Kepala TK Rumah Pelangi terlebih dahulu. Setelah itu, guru-guru tersebut dikumpulkan dan diajak bermusyawarah dengan tim pelaksana. Musyawarah disini yaitu tentang Program Pelatihan yang akan dilaksanakan serta kendala-kendala yang dimungkinkan timbul dalam pelaksanaan program ini, sehingga dalam musyawarah ini bisa mendapatkan solusi akan kendala tersebut. Setelah akan dilakukan pendampingan serta pelatihan kepada khalayak sasaran. Metode pendekatan masalah dapat diuraikan pada Gambar sebagai berikut.

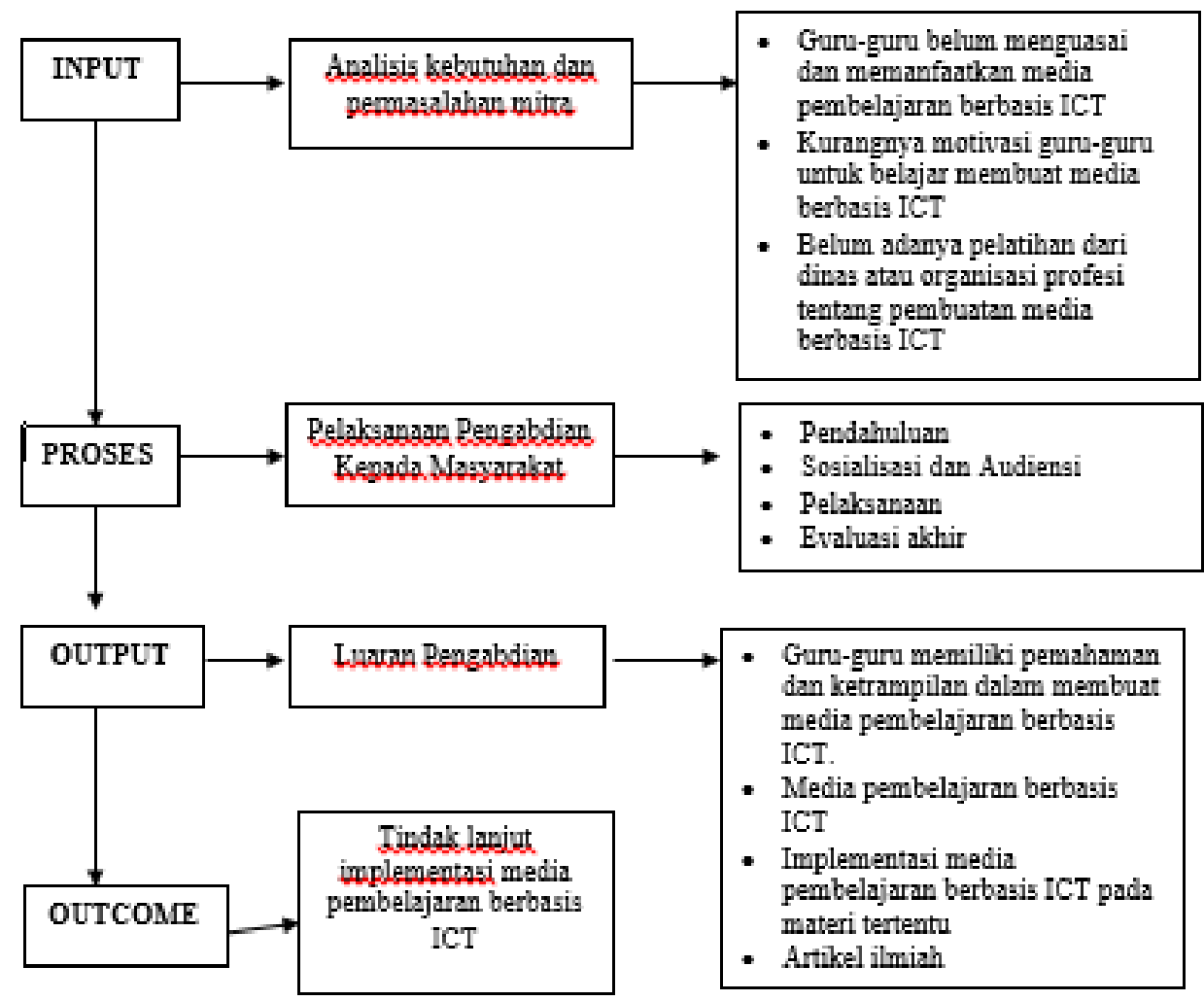




\section{HASIL YANG DICAPAI}

Hasil yang dicapai dari kegiatan pengabdian masyarakat ini adalah meningkatnya kemampuan dan keterampilan guru TK Rumah Pelangi, Dukuh Banukan RT.06/RW.09 DS. Malangjiwan, Colomadu, Karanganyar dalam membuat media pembelajaran berbasis ICT. Hal ini dapat dilihat dari antusias dari peserta pelatihan yang tinggi, mereka merasa sangat perlu pelatihan yang berkesinambungan karena setelah pelatihan banyak hal baru yang guru-guru dapatkan. Disamping wawasan guru bertambah dengan banyaknya program /aplikasi yang bisa digunakan untuk membuat media menarik, melalui pelatihan pembuatan media berbasis ICT ini guru langsung dapat menghasilkan media yang bisa digunakan dalam proses pembelajaran. Evaluasi Pra pelatihan hampir semua guru masih belum bisa menggunakan bahkan masih asing dengan program Flipbook, dan Comiclife, tetapi ada 3 guru sudah pernah menggunakan Powerpoin dalam pembelajaran, itupun juga membuat sebisanya karena belum semua tool mereka gunakan. Setelah dilakukanya pelatihan, kemudian dilakukan evaluasi pasca pelatihan didapat hasil yang melebihi target. Target awal hanya $80 \%$ atau 8 guru dari 10 guru yang bisa membuat powerpoin, flipbook dan comiclife, ternyata 90\% atau 9 guru dari 10 guru telah bisa membuat flipbook, comiclife dan powerpoin, 1 guru bisa membuat powerpoin saja.

Dari hasil tersebut bisa dikatakan bahwa pelatihan pembuatan media berbasis ICT ini berhasil. Kemampuan dan keterampilan yang telah didapat guru akan bisa diaplikasikan dalam proses pembelajaran dengan tema atau materi lain sesuai dengan kebutuhan.

\section{RENCANA TAHAPAN BERIKUTNYA}

Kegiatan pengabdian masyarakat ini merupakan suatu rangkaian tahapantahapan kegiatan yang akan direncanakan untuk kegiatan yang berkesinambungan. Setelah dilaksanakan pelatihan pembuatan media berbasis ICT kemudian diadakan pendampingan dalam mengevaluasi hasil-hasil media yang telah dibuat guru. Tahap berikutnya yang direncanakan adalah mengadakan kegiatan berupa pelatihan penggunaan aplikasi lain yang menunjang pembuatan media pembelajaran salah satu contohnya adalah Macromedia flash. Dengan diadakan pelatihan ini diharapkan guru semakin punya banyak perbendaharaan aplikasi yang dapat digunakan guru untuk membuat media yang menarik dan lebih bervariasi. Secara tidak langsung guru juga diasah kreativitasnya dalam mendesain, mengembangkan, mengelola, dan mengevaluasi media yang telah dibuatnya. 


\section{KESIMPULAN DAN SARAN}

\section{Kesimpulan}

Berdasarkan uraian sebelumnya maka dapat disampaikan bahwa kegiatan pengabdian masyarakat bagi guru TK Rumah Pelangi, Dukuh Banukan RT.06/RW.09 DS. Malangjiwan, Colomadu, Karanganyar menghasilkan kesimpulan sebagai berikut:

1. Upaya peningkatan pemahaman tentang wawasan penggunaan media berbasis ICT telah disampaikan dalam pelatihan.

2. Peserta antusias dalam mengikuti jalanya pelatihan karena merupakan hal yang baru dan menarik.

3. Pelatihan pembuatan media berbasis ICT yang dilaksanakan dapat meningkatkan kemampuan dan keterampilan guru. 9 guru telah dapat membuat media berbasis ICT.

\section{Saran}

Berdasarkan kesimpulan di atas dapat dikemukakan beberapa saran sebagai berikut:

1. Program pelatihan seharusnya dilakukan berkelanjutan dan dilakukan pendampingan pasca pelatihan supaya media yang dibuat maksimal.

2. Untuk memperlancar proses pelatihan, sebelumnya guru harus terbiasa mengoperasikan laptop/ komputer.

3. Sarana dan prasarana lembaga harus memadai.

\section{DAFTAR PUSTAKA}

Edy, H. 2008. Teknologi Informasi dan Komunikasi: Bandung: Pustaka Setia.

Joni, T. R. 2006. Standar Kompetensi Profesional Guru. Makalah disajikan dalam Komisi Khusus PGSD di Jakarta.

Kemendiknas. 2010. Pedoman Pelaksanaan Penilaian Kinerja Guru (PK). Jakarta: Dirjen Peningkatan

Rahman.R. J., Setiawan, W. \& Fitrajaya, R. E. 2008. Optimalisasi Macromedia Flash untuk Mendukung Pembelajaran Berbasis Komputer Pada Program Studi Ilmu Komputer FPMIPA UPI. Jurnal Pendidikan Teknologi Informasi Dan komunikasi 1(2) 19799264. 
Savittree , R. A., Padilla, M.J., and Tunhikorn, B. 2008. The Development of Pre service science teachers Professional Knowledge in Utilizing ICT to Support Professional lives. Eurasia journal of mathematics, science \& technology education, 5(2), 91-101. 